\title{
Reflex PAN to Buli in North Maluku
}

\author{
Burhanuddin \\ Postgraduate Doctoral of Linguistics \\ and Departement Language and Art \\ Universitas Sebelas Maret (UNS) \\ and Universitas Mataram (Unram) \\ Surakarta and Mataram, Indonesia \\ burhanuddin.fkip@unram.ac.id
}

\author{
Nur Ahmadi \\ Lecturer Departement of Education \\ Language and Art \\ Universitas Mataram (Unram) \\ Mataram, Indonesia \\ nurahmadi@unram.ac.id
}

\author{
Ratna Yulida \\ Lecturer Departement of Education \\ Language and Art \\ Universitas Mataram (Unram) \\ Mataram, Indonesia \\ whlombok@gmail.com
}

\begin{abstract}
Buli language belongs to one of Austronesian languages, South Halmahera-West New Guinea, the Subgroup of South Halmahera. As a member of Austronesian languages, this article intends to present linguistic evidence, phonological aspects which may clarify and highlight the issues. The explanation to the issues applies a top-down approach by considering the realization of ProtoAustronesian phoneme into Buli language. The results of identification process indicate that there are PAN's phonemes which are still retained and those having undergone innovation. Both those reflexes belonging to retention and innovation can each be regular and nonregular.
\end{abstract}

Keywords: reflex, Proto-Austronesia, top-down approach, retention, innovation

\section{INTRODUCTION}

Historically lingustically, Buli is included in the Southern Halmahera Group, South Halmahera-West New Guinea, along with the Maba / Patani, Sawai, Gane, Taba, and Gebe languages. Regarding this group, Blust (1978) did not include Gebe in this subgroup, but Kamholz (2014) and Burhanuddin (2017) included it. According to Blust (1978) and Kamholz (2014), the languages of South Halmahera are comprised of two subgroups, the Central-Eastern South Halmahera and Southern-South Halmahera. The Central-Eastern South Halmahera subgroup consists of Buli, Maba/Patani, Sawai, and Gebe. Now SouthernSouth Halmahera is made up of Gane and Taba. Blust (1978) there is no linguistic evidence of grouping with keywords of phonological and lexical similarities, except Kamholz (2014). Kamholz (2014), supports the grouping, by proposing morphological evidence of the multiple plural subject plots for afik $\{\mathrm{f}-\}$ for the Southern Halmahera Subgroup, for the CentralEastern South Halmahera languages having the first inalienable marker belonging to the plural inclusive $\{-\mathrm{r} / \mathrm{-d}\}$. In addition, bookmark storage is inalienable for Southern-South Halmahera languages, whereas in the Central-Eastern South Halmahera languages. As the evidence of phonology and lexicons explaining this historical relation is not specific.

The language of Buli is used in East Halmahera District, Buli Sub-district, Buli Village and Buli Origin of North Maluku Province, with a total number of speakers of approximately 2,520 (Lewis et al., 2017). In North Maluku there are two language families, namely Austronesia (AN) and Non-Austronesian (NAN). Austronesian languages are commonly used in South Halmahera, whereas Non-Austronesian languages are used in North Halmahera. The languages included in the Austronesian clan are Buli, Maba, Sawai, Gebe, Gane, Taba, while the Non-Austronesians are Tobelo, Galela, Ternate, Morotai, and Western Makian. Therefore, the Proto-Austronesian (PAN) reflex study into Buli is one of the attempts to prove Buli as a member of the Austronesian or Non-Austronesian family.

This paper does not intend to present the evidence of phonology and lexicon about the classification of geneology, because it must involve five other languages. This paper only presents a picture of the Proto-Austronesian phonemes reflex to Buli as a member of the South Halmahera Group as a first step to test the hypothesis. That is, looking at the Proto-Austronesian (PAN) reflex into the Buli language. Of course with the record of this study followed the study of PAN reflex in five other South Halmahera languages. In other words, this study is the first step to test the hypothesis about the historical relation of the languages of South Halmahera. In addition, this study is also important to see the pattern or type of sound changes in Buli language itself.

\section{METHOD}

To answer the problem to be explained, data collection has been collected using library method by collecting PAN etimon that has been reconstructed by Trussell and Blust (2015) in Austronesian Comparative Dictionary. In addition, an interview method was used to collect 200 revised basic vocabularies of Blust (1980) and 800 cultural vocabularies contained in Buli. The collected data is then analyzed using a top-down approach, a method of shared innovation (Adelaar, 2005; Blust, 2008 and 2013; and Holton and Robinson, 2014)). A top-down approach is used to view the realization of PAN changes into Buli, both in the form of retention and innovation. 


\section{FINDING AND DISCUSSION}

Before the PAN reflex is proposed in Buli, it is worth mentioning the kind of PAN phonemes reconstructed by Blust (2013). According to Blust (2013), PAN phonem consists of 24 consonants (/p, t, C, c, k, q, b, d, z, j, g, N, m, n, n, y, s, S, h, 1, r, R, y, and w/), four vowels (/ i, u, ə, and a/), and four diphthongs (-aw, -ay, -uy, dan -iy). These phonemes are the basis for seeing their realization in Buli. As for the results of Burhanuddin's (2017) identification, in Buli language consists of 20 consonants (/p, $\mathrm{t}, \mathrm{c}, \mathrm{k}$, $\mathrm{q}, \mathrm{n}, \mathrm{n}, \mathrm{y}, \mathrm{s}, \mathrm{h}, \mathrm{l}, \mathrm{r}, \mathrm{y}$, and $\mathrm{w} /$ ) and eight vowels $(/ \mathrm{i}, \mathrm{u}, \mathrm{\partial}, \mathrm{e}, \mathrm{\varepsilon}, \mathrm{a}, \mathrm{o}$, and $\mathrm{\rho} /)$. Here is presented how the reflection of PAN into the language of Buli.

A. $P A N * p$

PAN *p changes to /f/ regulary in Buli language at the initial and intervocal position, whereas at the end position is irregular (and it is possible that the properties are regular if the data is expanded). In addition to being /f/, PAN *p changes to / $\varnothing /$ in the final position, as well as in the initial position of retention, each of which is irregular.

\begin{tabular}{|c|c|c|c|}
\hline Gloss & PAN & Buli & Rule \\
\hline when & *pica & offhis & $* \mathrm{p}>\mathrm{f} / \#-$ \\
\hline stingray & *paRi & fa & \\
\hline turtle & *pәлu? & fen, etc & \\
\hline pare & *paria? & pəpare & $* p>p / \#-$ \\
\hline thin & $*$ tipis & mlifis & $* \mathrm{p}>\mathrm{f} / \mathrm{H}-\#$ \\
\hline four & *Səpat & pifaat & \\
\hline taste & *təpəy & tofan, etc & \\
\hline centipede & *Sipan & lilitan & $* \mathrm{p}>\mathrm{t} / \#-\#$ \\
\hline roof & *Patəp & yataf & $* \mathrm{p}>\mathrm{f} / \mathrm{H}-\#$ \\
\hline blow & *tiyup & ufaq & \\
\hline smoke & *Pasəp & memeyas & $* p>\varnothing /-\#$ \\
\hline
\end{tabular}

\section{B. PAN *t}

PAN *t is still maintained in Buli language at all positions. Only, in the initial position and the inter-vocalic is regular, while the final position is irregular.

\begin{tabular}{|c|c|c|c|}
\hline Gloss & PAN & Buli & Rule \\
\hline three & $*$ təlu & pitol & $* \mathrm{t}>\mathrm{t} / \#-$ \\
\hline taste & *tәрәп & tofayo & \\
\hline thin & $*$ tipis & mlifis & \\
\hline blow & *tiyup & ufaq, etc & \\
\hline roof & *?atəp & yataf & $* \mathrm{t}>\mathrm{t} / \#-\#$ \\
\hline lice & *kutu & ut & \\
\hline moss & *lumut & lulumit, etc & \\
\hline coconut fiber & *bunut & punit & $* \mathrm{t}>\mathrm{t} /-\#$ \\
\hline sea & *lahut & olat & \\
\hline
\end{tabular}

\section{C. $P A N * C$}

PAN * $\mathrm{C}$ in all positions changed to / $\mathrm{t} /$ in Buli language, ie at the initial and final position is irregular, while the final position is regular.

\begin{tabular}{|c|c|c|c|}
\hline Gloss & PAN & Buli & Rule \\
\hline cry & *Cayis & (n)tanis & $* \mathrm{C}>\mathrm{t} / \#-$ \\
\hline year & *CawiN & taun & \\
\hline die & *maCay & mat & $\mathrm{C}>\mathrm{t} / \mathrm{\#}$ \\
\hline
\end{tabular}




$\begin{array}{llll}\text { eye } & * \text { maCa } & \text { mta } & \\ \text { egg } & \text { *PiColuR } & \text { tolo } & \\ \text { sky } & \text { *layiC } & \text { lajit } & * \mathrm{C}>\mathrm{t} / \text {-\# }\end{array}$

D. PAN *k

PAN * $\mathrm{k}$ in Buli language is still preserved in the initial position and is regular. In addition, PAN *k at the initial position changes to $/ \mathrm{m} /, / \mathrm{b} /$, and $/ \mathrm{g} /$, while in the final position disappears, which of which is irregular. Only in the inte-vocalic position is regularly changed to $/ \varnothing /$.

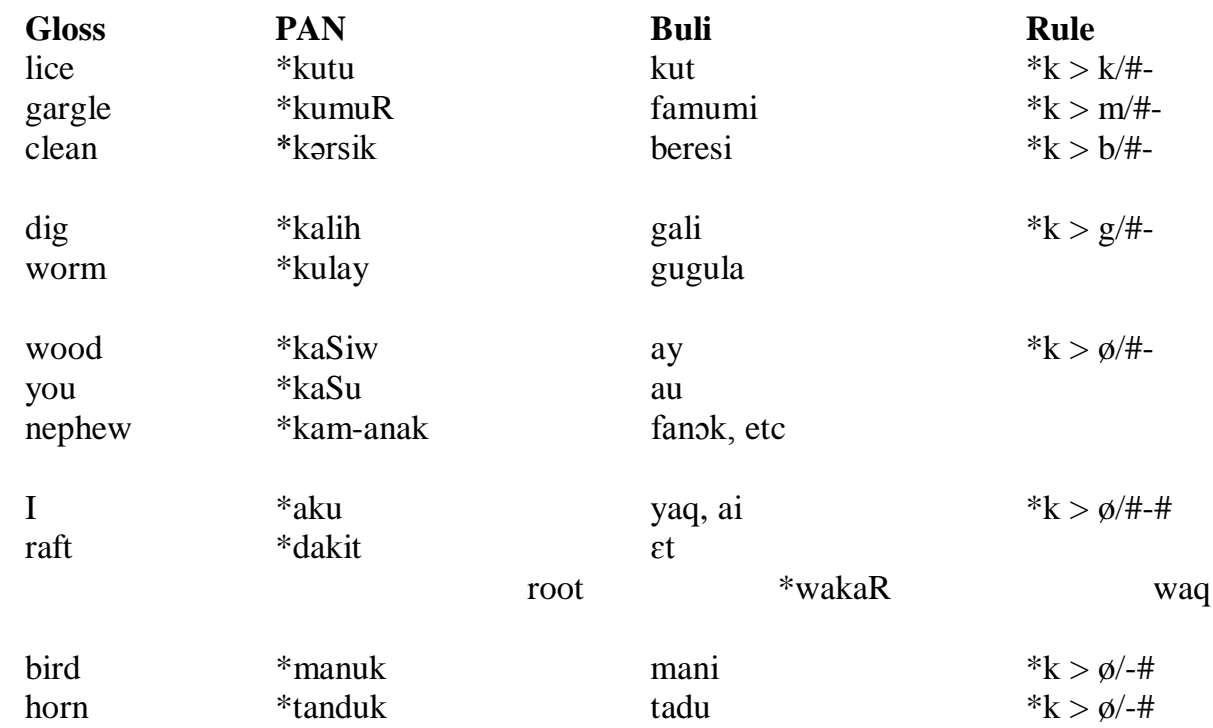

\section{E. $P A N * ?$}

PAN * $?$ nothing is preserved in Buli, but innovated in all positions. Innovation PAN * $P$ in initial position to /g/, /ø/,/y//f/, $/ \mathrm{m} /, / \mathrm{n} /, / \mathrm{t} /, / \mathrm{w} /$; be $/ \varnothing /$ in the inter-vocalic position; and be /f/ and /s/ at the final position of which is irregular. The change to / $/$ at the final position occurs regularly.

\begin{tabular}{|c|c|c|c|}
\hline Gloss & PAN & Buli & Rule \\
\hline salt & *PasiRa & gasi? & $* \mathrm{p}>\mathrm{g} / \#-$ \\
\hline egg & *PiColuR & tolo & $* ?>\varnothing / \#-$ \\
\hline salty & *Pasin & payasin & $* q>y / \#-$ \\
\hline roof & *?atəp & yataf & \\
\hline married & * Pasawa & fasaw & $* ?>\mathrm{f} / \#-$ \\
\hline gargle & *?umuR & famumi & $* \mathrm{p}>\mathrm{m} / \#-$ \\
\hline sand & *Pənay & nijen & $* \mathrm{p}>\mathrm{n} / \#-$ \\
\hline cucumber & * Patimun & titimin & $* \mathrm{P}>\mathrm{t} / / \#-$ \\
\hline shark & *PiSu & woi & $* \mathrm{P}>\mathrm{w} / \mathrm{H}-$ \\
\hline thigh & *pa?a & fiar & *? > $/ \#-\#$ \\
\hline pee & *mi?mi? & panama & \\
\hline blood & *daRa? & laflaf & $* ?>\mathrm{f} / \mathrm{- \#}$ \\
\hline swollen & *baRə? & bos & $* ?>\mathrm{s} /-\#$ \\
\hline water pee & *kəmi? & fanami & $* ?>\emptyset /-\#$ \\
\hline pare & *paria? & pəpare & \\
\hline turtle & *pәлu? & fen & \\
\hline
\end{tabular}


F. $P A N * b$

PAN * b changes to / $\mathrm{p} /$ occurs on a regular basis, whereas $/ \mathrm{b} /$ and $/ \mathrm{m} /$ occurs irregularly. The inter-vocal position becomes $/ \mathrm{p} /, / \mathrm{f} /$, and $/ \varnothing /$ each is irregular.

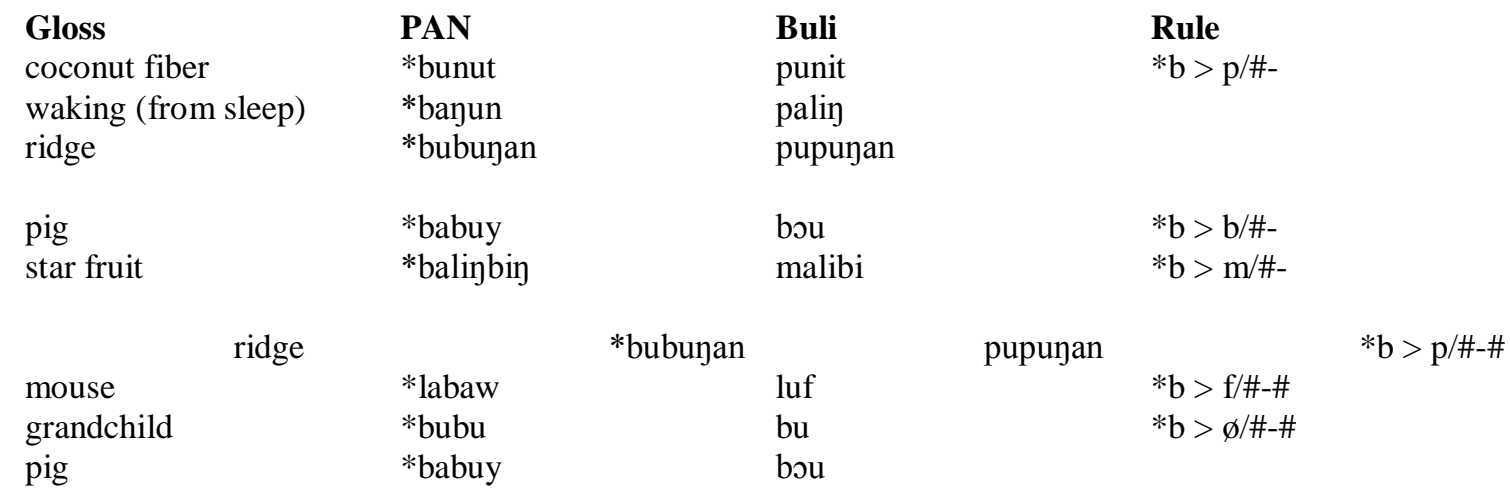

\section{G. $P A N * d$}

PAN $* \mathrm{~d}$ at initial position innovates to /l/ regularly and becomes /t/ irregularly. In addition, PAN $* \mathrm{~d}$ becomes / $\varnothing /$ at the initial and inter-vocalic positions are irregular respectively.

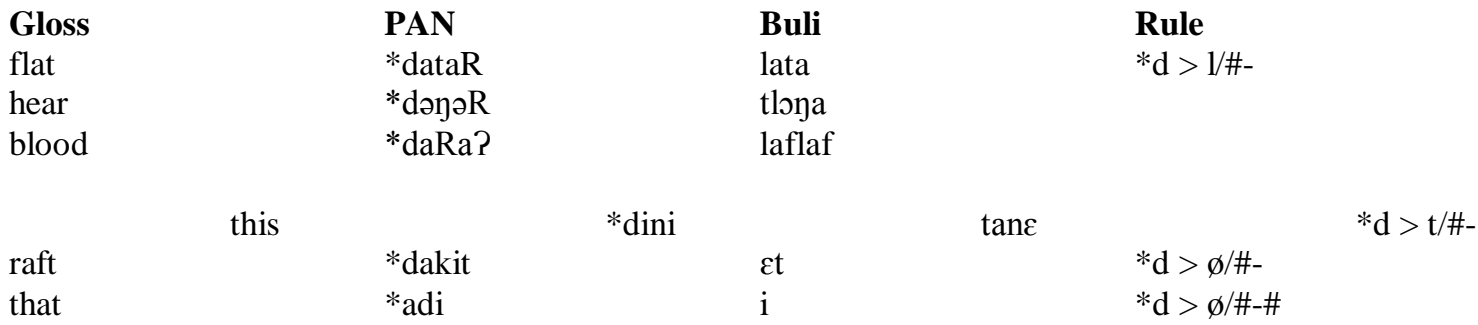

\section{H. $P A N * z . * j, * g$}

PAN $* \mathrm{z}$ changes to /f/ is irregular in initial position. PAN $* \mathrm{j}$ in the inter-vocal position to $/ \mathrm{h} /$, in the final position to /t/, wich is irregular. As for, PAN *g being /g/ in the initial position occurs irregularly.

\begin{tabular}{|c|c|c|c|}
\hline Gloss & PAN & Buli & Rule \\
\hline Walk & *zalan & fan & $*_{\mathrm{Z}}>\mathrm{f} / \#-$ \\
\hline name & *yajan & yahno & $* \mathrm{j}>\mathrm{h} / \#-\#$ \\
\hline worm & *Puləj & gugulat & $* \mathrm{j}>\mathrm{t} /-\#$ \\
\hline scratch & $*_{\text {garut }}$ & gag & $* \mathrm{~g}$ \\
\hline
\end{tabular}

I. $P A N * m$

PAN *m in inter-vocal retention regularly, whereas at the initial and final positions are irregular. In addition, PAN $* \mathrm{~m}$ in the inter-vocal position changes to /ø/ irregularly.

\begin{tabular}{|c|c|c|c|}
\hline Gloss & PAN & Buli & Rule \\
\hline bird & *manuk & mani & $* \mathrm{~m}>\mathrm{m} / \#-$ \\
\hline eye & $*_{\mathrm{maCa}}$ & $\mathrm{mta}$ & \\
\hline hand & *kamay & kakamıq & $* \mathrm{~m}>\mathrm{m} / \#-\#$ \\
\hline cucumber & *Patimun & titimin & \\
\hline five & *lima & pilim & \\
\hline you & *Simu & $\mathrm{au}$ & $* \mathrm{~m}>\emptyset / \#-\#$ \\
\hline nephew & *kam-anak & fanok & \\
\hline six & *ənəm & wonam & $* \mathrm{~m}>\mathrm{m} /-\#$ \\
\hline
\end{tabular}


drink

*inum

dom

\section{J. $P A N * n$}

$\mathrm{PAN} * \mathrm{n}$ in the initial position changes to $/ \mathrm{d} /$ and $/ \mathrm{n} /$ which are irregular in nature, whereas in the final position it becomes $/ \mathrm{n}$, $\mathrm{y}, 1$, and $\mathrm{n} /$ which are irregular in nature. Changes to $/ \mathrm{n} /$ and $/ \mathrm{y} /$ are possible to occur regularly if the data is expanded. PAN $* \mathrm{n}$ in the middle position changes to $/ \mathrm{n} /$ and at the end position to $/ \mathrm{n} /$, each irregularly.

\begin{tabular}{|c|c|c|c|}
\hline Gloss & PAN & Buli & Rule \\
\hline drink & *inum & dom & $* \mathrm{n}>\mathrm{d} / \#-$ \\
\hline bird & *manuk & mani & $* \mathrm{n}>\mathrm{n} / \#-$ \\
\hline ridge & *bubuyan & pupunan & $* n>n /-\#$ \\
\hline cucumber & *Patimun & titimin & \\
\hline centipede & *Sipan & lilitan & $*_{n}>\mathrm{y} /-\#$ \\
\hline salty & *Pasin & payasin & \\
\hline name & *yajan & yahno & $*_{\mathrm{n}}>\mathrm{j} /-\#$ \\
\hline waking (from sleep) & *bayun & palin & $*_{n}>1 /-\#$ \\
\hline
\end{tabular}

K. PAN *N, *n, and $*_{\eta}$

PAN * $\mathrm{N}$ at the initial position turns into PHS *m, *1, and $* \mathrm{~S}$ each occurring irregularly. Likewise in the end position experiencing irregular retention.

$\begin{array}{llll}\text { Gloss } & \text { PAN } & \text { Buli } & \text { Rule } \\ \text { see } & \text { *Noy } & \text { mem } & * \mathrm{~N}>\mathrm{m} / \#- \\ \text { sap } & \text { *Nitə? } & \text { litlit } & * \mathrm{~N}>1 / \#- \\ \text { breath } & \text { *NiSawa } & \text { tawaq } & * \mathrm{~N}>\varnothing / \#- \\ \text { year } & \text { *CawiN } & \text { taun } & * \mathrm{~N}>\mathrm{n} / \text {-\# }\end{array}$

PAN $* n$ in the initial position of retention and $/ \mathrm{n} /$ in the inter-vocal position, each of which occurs irregularly. As for, PAN $* \mathrm{y}$ at all position have retention irregulary. In addition to retention, PAN *y changes to /ø/ in the inter-vocal and final positions that occur irregularly. At the final position, PAN *y also changes to $/ \mathrm{m} /$ irregularly.

\begin{tabular}{|c|c|c|c|}
\hline Gloss & PAN & Buli & Rule \\
\hline dew & *namuR & ninemi & $*_{\mathrm{n}}>\mathrm{n} / \#-$ \\
\hline turtel & *pәлu? & fen & $*_{\mathrm{n}}>\mathrm{n} / \#-\#$ \\
\hline name & *yanan & yahyo & $*_{\mathrm{y}}>\mathrm{y} / \#-$ \\
\hline sky & *laniC & lanit & $*_{y}>\mathrm{y} / \#-\#$ \\
\hline star fruit & *balinbin & malibi & $* \eta>\varnothing / \#-\#$ \\
\hline taste & *təpəy & tofay & $*_{y}>\mathrm{y} /-\#$ \\
\hline see & *Nay & $\mathrm{mem}$ & $* \eta>m /-\#$ \\
\hline star fruit & *balinbin & malibi & $*_{\eta}>\varnothing /-\#$ \\
\hline
\end{tabular}

L. PAN *s

PAN *s retains at all positions, only in the inter-vocal position that occurs regularly, whereas in the initial and final positions occur irregularly. In addition, PAN *s has innovated to /c/ in the initial position, being /w/ and / $\varnothing /$ in the inter-vocal position, each irregular.

Gloss

nine

milk

salt

one

clean

milk
PAN

*siwa

*susu

* PasiRa

*isa

*kərsik

*susu
Buli

siwe

cuway

gasiq

$\mathrm{p}(\mathrm{i}, \mathrm{u}) \mathrm{sa}$

beresi, etc

cuway
Rule

*s > s/\#-

$*_{\mathrm{s}}>\mathrm{c} / \#$ -

*s > s/\#-\#

*s > w/\#-\# 

gum
*gusi
igo
$*_{\mathrm{s}}>\varnothing / \#-\#$
cry
*Canis
(n)tanis
$*_{\mathrm{s}}>\mathrm{s} /-\#$

M. $P A N * S$

PAN *s at initial position changes to /p, $1, \varnothing /$ in Buli, each is irregular. In the inter-vocal position changes to / $\varnothing /$ regularly and /y/ irregularly. The final position changes to /s/ irregularly.

\begin{tabular}{|c|c|c|c|}
\hline Gloss & PAN & Buli & Rule \\
\hline four & *Səpat & pifaat & $* \mathrm{~S}>\mathrm{p} / \#-$ \\
\hline centipede & *Sipan & lilitan & $* S>1 / \#-$ \\
\hline wash (hand) & *SuraS & uwas & $* \mathrm{~S}>\varnothing / \#-$ \\
\hline you & $* \mathrm{kaSu}$ & $\mathrm{au}$ & $* S>\varnothing / \#-\#$ \\
\hline wood & *kaSiw & ay & \\
\hline shark & *PiSu & woi & \\
\hline breath & *NiSawa & tawaq & \\
\hline water & ${ }^{*}$ waSiR & waya & $* \mathrm{~S}>\mathrm{y} / \#-\#$ \\
\hline tuma (lice egg) & *lisə?əS & lowas & $* \mathrm{~S}>\mathrm{s} /-\#$ \\
\hline wash (hand) & *SuraS & uwas & \\
\hline
\end{tabular}

O. $P A N * h$ and $* l$

PAN $* \mathrm{~h}$ in the inter-vocal position and the end turns to PHS $* \varnothing$ irregularly, so also the change to / s / at the end position occurs irregularly.

$\begin{array}{llll}\text { Gloss } & \text { PAN } & \text { Buli } & \text { Rule } \\ \text { sea } & \text { *lahut } & \text { olat } & * \mathrm{~h}>\emptyset / \#-\# \\ \text { keep } & \text { *jagah } & \text { jaga } & * \mathrm{~h}>\varnothing /-\# \\ \text { dig } & \text { *kalih } & \text { gali } & \\ \text { thin } & \text { *pipih } & \text { malifis } & * \mathrm{~h}>\mathrm{s} /-\#\end{array}$

PAN *1 undergoes irregular retention in all positions, while in the inter-vocal position also innovates to / $/$ irregularly.

Gloss

sky

lalat

$\operatorname{dig}$

walk

*laniC

*layaw

*kalih

*bəyəl

deaf

\section{Buli}

lanit

lan

gali

*Zalan
Rule

*1 > 1/\#-

*1 > 1/\#-\#

fan
$* 1>\varnothing / \#-\#$

lonapaq

*1 $>1 /$-\#

P. $P A N * r$ and $* R$

PAN *r retains regular inter-vocal position in Buli. In addition, PAN *r has been innovated to /w/ and / $\varnothing /$ irregularly in intervocal positions.

Gloss

pare

clean

wash (hand)

scratch
PAN

*paria?

*kərsik

*SuraS

* garut

\section{Buli}

pəpare

beresi

uwas

gag
Rule

*r $>$ r/\#-\#

*r $>\mathrm{w} / \#-\#$

$*_{\mathrm{r}}>\varnothing / \#-\#$

PAN $* \mathrm{R}$ in the inter-vocal and final position changes to $* \varnothing$ irregularly. The final position changes to /P/ irregularly.

\section{Gloss}

salt

stingray

blood

swollen
PAN

*PasiRa

*paRi

*daRa?

*baRə?
Buli

gasi?

fa

laflaf

bos
Rule

$* \mathrm{R}>\varnothing / \#-\#$ 


$\begin{array}{llll}\text { gargle } & \text { *kumuR } & \text { famumi } & * \mathrm{R}>\varnothing /-\# \\ \text { hear } & \text { *də⿹əR } & \text { tlona } \\ \text { egg } & \text { tolo } & \\ \text { water } & \text { *waSiR } & \text { waya? } & * \mathrm{R}>\mathrm{P} / \text {-\# }\end{array}$

Q. $P A N * w$ and $* y$

PAN $*_{W}$ retains regularly in the inter-vocal position, while in the initial position has irregular retention. In addition, in the inter-vocal position, PAN * $\mathrm{w}$ undergoes irregular changes to $/ \varnothing /$ in the inter-vocal position. The PAN *y in the inter-vocal position experienced deletion in the inter-vocal position irregularly.

\begin{tabular}{|c|c|c|c|}
\hline Gloss & PAN & Buli & Rule \\
\hline eight & *walu & piway & $*_{\mathrm{W}}>\mathrm{w} / \#-$ \\
\hline \multirow[t]{2}{*}{ water } & *waSiR & wayaq & \\
\hline & root & *wakaR & waq \\
\hline married & *?asawa & fasaw & $*_{\mathrm{W}}>\mathrm{w} / \mathrm{H}-\#$ \\
\hline nine & *siwa & siwe & \\
\hline year & *CawiN & taun & $*_{\mathrm{W}}>\varnothing / \#-\#$ \\
\hline blow & tiyup & ufaq & $* y>\varnothing / \#-\#$ \\
\hline
\end{tabular}

\section{R. $P A N * a$}

PAN *a experiences irregular retention and experiences irregular erosion of each in all positions. In the penultimate syllabe, PAN * a changes to /a/ irregularly. In the ultima silabe turns into /o/ and /e/ each occurs irregularly. As for the final position, PAN *a changes to /e/, /o/, and /aw/ each occurs irregularly.

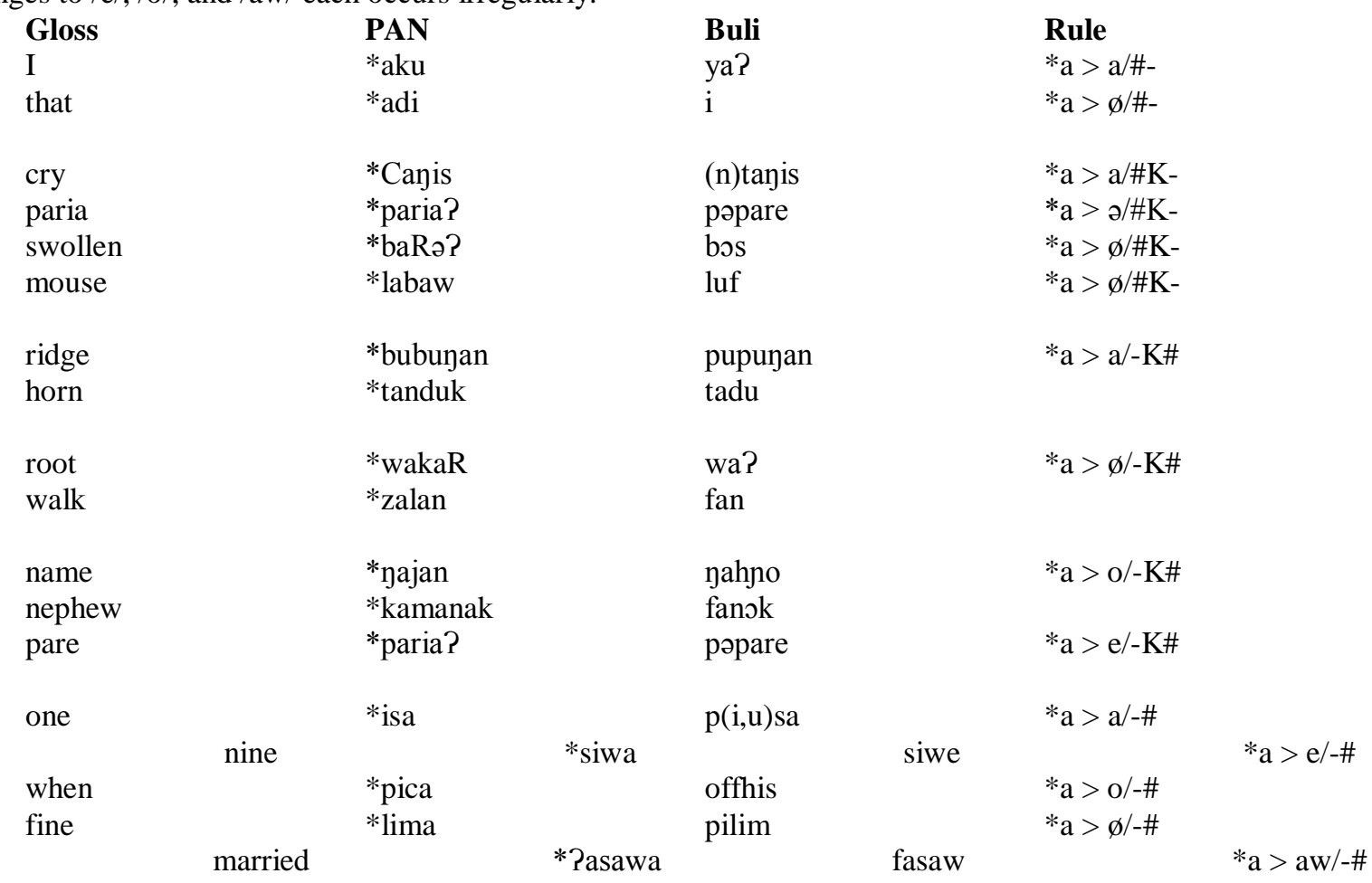

\section{S. $P A N * \partial$}

PAN * $*_{\partial}$ becomes $/ \mathrm{s} /$ at the initial position, into $/ \varepsilon /$ at the penultimate and ultima silabes, into /i/ on the penultimate silabe, and into $/ \mathrm{e} /$ and $/ \varnothing /$ on the ultima silabe each occurring irregularly. The change to $/ \mathrm{\rho} / \mathrm{on}$ the penultimate silabe and /a/ on the ultima silabe each occurs on a regular basis.

Gloss

PAN
Buli

Rule 


\begin{tabular}{|c|c|c|c|}
\hline six & *ənəm & wonam & $*_{\partial}>0 / \#-$ \\
\hline $\begin{array}{l}\text { egg } \\
\text { hear } \\
\text { taste } \\
\text { three }\end{array}$ & $\begin{array}{l}\text { *PiCəluR } \\
\text { *dəyəR } \\
\text { *təpəy } \\
\text { *təlu }\end{array}$ & $\begin{array}{l}\text { tolo } \\
\text { tloya } \\
\text { tofan } \\
\text { pitol, etc }\end{array}$ & $*_{\partial}>\rho / \# \mathrm{~K}-$ \\
\hline $\begin{array}{l}\text { four } \\
\text { sand }\end{array}$ & $\begin{array}{l}\text { *Sopat } \\
\text { *Pənay }\end{array}$ & $\begin{array}{l}\text { pifaat } \\
\text { ninen }\end{array}$ & $*_{\partial}>\mathrm{i} / \# \mathrm{~K}-$ \\
\hline turtle & *pəли? & fen & $*_{\partial}>\varepsilon / \# \mathrm{~K}-$ \\
\hline $\begin{array}{l}\text { taste } \\
\text { hear } \\
\text { six }\end{array}$ & 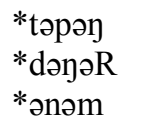 & $\begin{array}{l}\text { tofan } \\
\text { tloya } \\
\text { wonam, etc }\end{array}$ & $*_{\partial}>\mathrm{a} /-\mathrm{K} \#$ \\
\hline $\begin{array}{l}\text { swollen } \\
\text { smoke }\end{array}$ & $\begin{array}{l}\text { *baRə? } \\
\text { *?asəp }\end{array}$ & $\begin{array}{l}\text { bos } \\
\text { memeyas }\end{array}$ & $*_{\partial}>\varnothing /-\mathrm{K} \#$ \\
\hline $\begin{array}{l}\text { clean } \\
\text { see }\end{array}$ & $\begin{array}{l}\text { *kərsik } \\
\text { *Nəy }\end{array}$ & $\begin{array}{l}\text { beresi } \\
\mathrm{m \varepsilon m}\end{array}$ & $\begin{array}{l}*_{\partial}>\mathrm{e} /-\mathrm{K} \# \\
*_{\partial}>\varepsilon /-\mathrm{K} \#\end{array}$ \\
\hline
\end{tabular}

\section{T. $P A N * i$}

PAN $* i$ in Buli, on the penultimate and ultima silabes having their respective retention regularly. PAN $* i$ also experienced retention at both start and end positions but each was irregular. In addition to being /i/, PAN $* \mathrm{i}$ is in the initial position and becomes $/ \varnothing /$, becomes $/ \mathrm{u} /$ and $/ \varepsilon /$ on the ultima sylabe, each occurring regularly.

\begin{tabular}{|c|c|c|c|}
\hline $\begin{array}{l}\text { Gloss } \\
\text { drink } \\
\text { one }\end{array}$ & $\begin{array}{l}\text { PAN } \\
*_{\text {inum }} \\
\text { *isa }_{\text {isa }}\end{array}$ & $\begin{array}{l}\text { Buli } \\
\text { dom } \\
\text { p(u,i)sa }\end{array}$ & $\begin{array}{l}\text { Rule } \\
*_{\mathrm{i}}>\varnothing / \#- \\
*_{\mathrm{i}}>\mathrm{i} / \#-\end{array}$ \\
\hline $\begin{array}{l}\text { cucumber } \\
\text { five } \\
\text { when }\end{array}$ & $\begin{array}{l}\text { * Patimun } \\
\text { *lima } \\
\text { *pica }\end{array}$ & $\begin{array}{l}\text { titimin } \\
\text { pilim } \\
\text { offhis, etc }\end{array}$ & $*_{\mathrm{i}}>\mathrm{i} / \#-\mathrm{K}$ \\
\hline $\begin{array}{l}\text { blow } \\
\text { egg }\end{array}$ & $\begin{array}{l}\text { *tiyup } \\
\text { * PiColuR }\end{array}$ & $\begin{array}{l}\text { ufaq } \\
\text { tolo }\end{array}$ & $*_{\mathrm{i}}>\varnothing / \# \mathrm{~K}-$ \\
\hline $\begin{array}{l}\text { sky } \\
\text { water pee } \\
\text { star fruit }\end{array}$ & $\begin{array}{l}\text { *laniC } \\
\text { *mi?mi? } \\
\text { *balinbin }\end{array}$ & $\begin{array}{l}\text { lanit } \\
\text { fanami } \\
\text { malibi, etc }\end{array}$ & $*_{\mathrm{i}}>\mathrm{i} /-\mathrm{K} \#$ \\
\hline $\begin{array}{l}\text { year } \\
\text { raft }\end{array}$ & $\begin{array}{l}* \text { CawiN } \\
* \text { dakit }\end{array}$ & $\begin{array}{l}\text { taun } \\
\varepsilon \mathrm{t}\end{array}$ & $\begin{array}{l}*_{\mathrm{i}}>\mathrm{u} /-\mathrm{K} \# \\
*_{\mathrm{i}}>\varepsilon /-\mathrm{K} \#\end{array}$ \\
\hline $\begin{array}{l}\text { stingray } \\
\text { gum }\end{array}$ & $\begin{array}{l}\text { *paRi } \\
\text { *gusi }\end{array}$ & $\begin{array}{l}\text { fa } \\
\text { igo }\end{array}$ & $\begin{array}{l}* \mathrm{i}>\varnothing /-\# \\
*_{\mathrm{i}}>\mathrm{i} /-\#\end{array}$ \\
\hline
\end{tabular}

\section{U. $P A N * u$}

PAN $* u$ in the ultima silabe becomes /i/ and the final position becomes / $\varnothing /$ each occurs regularly, whereas it becomes $* \mathrm{i}$ and $*_{\mathrm{a}}$ irregular. In the initial position to be $/ \mathrm{u} /$ and $/ \mathrm{o} /$, be $/ \mathrm{o} /$ and $/ \varnothing /$ in the ultima silabe, and $/ \mathrm{u} /$ and $/ \mathrm{o} /$ in the final position, each occurring irregularly.

Gloss

moss

ridge

gum
PAN

*lumut

*bubuyan

*gusi
Buli

lulumit

pupuyan

igo
Rule

$* \mathrm{u}>\mathrm{u} / \# \mathrm{~K}$ -

$* \mathrm{u}>\mathrm{o} / \# \mathrm{~K}-$ 


\begin{tabular}{|c|c|c|c|}
\hline $\begin{array}{l}\text { cucumber } \\
\text { moss } \\
\text { bird }\end{array}$ & $\begin{array}{l}\text { *Patimun } \\
\text { *lumut } \\
\text { *manuk }\end{array}$ & $\begin{array}{l}\text { titimin } \\
\text { lulumit } \\
\text { mani, etc }\end{array}$ & $* u>i /-K \#$ \\
\hline $\begin{array}{l}\text { egg } \\
\text { sea }\end{array}$ & $\begin{array}{l}\text { *2iCəluR } \\
\text { *lahut }\end{array}$ & tolo & $* u>s /-K \#$ \\
\hline drink & *inum & dom & $* \mathrm{u}>\varnothing /-\mathrm{K} \#$ \\
\hline $\begin{array}{l}\text { milk } \\
\text { lice } \\
\text { I } \\
\text { three }\end{array}$ & $\begin{array}{l}\text { *susu } \\
\text { *kutu } \\
\text { *aku } \\
\text { *təlu }\end{array}$ & $\begin{array}{l}\text { sus } \\
\text { kut } \\
\text { ya? } \\
\text { pitol, etc }\end{array}$ & $* u>\varnothing /-\#$ \\
\hline $\begin{array}{l}\text { you } \\
\text { shark }\end{array}$ & $\begin{array}{l}\text { *kaSu } \\
* \text { PiSu }\end{array}$ & & $\begin{array}{l}* \mathrm{u}>\mathrm{u} /-\# \\
* \mathrm{u}>\mathrm{o} /-\#\end{array}$ \\
\hline
\end{tabular}

V. PAN *ay and*aw

PAN *-ay becomes $/ a /, / \varepsilon /, / J /$, and $/ \varnothing /$ at the final position which each is irregular. The PAN $*$ aw disappeared regularly at the final position in Buli.

\begin{tabular}{|c|c|c|c|}
\hline Gloss & PAN & Buli & Rule \\
\hline worm & *kulay & gugulat & $*$ ay $>$ a/-\# \\
\hline sand & *Pənay & ninen & $*$ ay $>\varepsilon /$-\# \\
\hline hand & *kamay & kakamıq & $*$ ay $>\mathrm{s} /$-\# \\
\hline die & *aCay & mat & $*$ ay $>\varnothing /-\#$ \\
\hline mouse & *labaw & luf & $*$ aw $>\varnothing /-\#$ \\
\hline
\end{tabular}

\section{CONCLUSION}

The above description implies that, PAN sounds are retention and innovation. Both retention and innovation, each of which occurs regularly and irregularly. The description of the PAN reflex into Buli is expected to be the first step in proving the Blust hypothesis (1978), in relation to the historical relation of the languages of South Halmahera. The South Halmahera languages are divided into two main sub-groups, namely the Central-Eastern South Halmahera (consisting of Buli, Maba/Patani, and Sawai) and Southern-South Halmahera (consisting of Gane and Taba). Of course, to prove the hypothesis, it takes a study that is similar to this study by taking four other languages of the study object. By knowing the tendency to change the reflex PaN into Buli language and the four other languages, it can be determined the form of innovation with the five languages so that it can be determined level or genealogy kinship in general.

\section{References}

Adelaar, K.A. (2005). Malayo-Sumbawan. Oceanic Linguistics Journal, Nomor 44: 357-388. Honolulu: University of Hawaii.

Blust, Robert A. (978). Eastern Malayo-Polynesian: a subgrouping argument. Halaman 181-234 Nomor 61 Pacific Linguistics Series C. Dalam S.A. Wurm and Lois Carrington (eds). Second international conference on Austronesian linguistics proceedings. Canberra: Department of Linguistics, Research Schools of Pacific Studies, The Australian National University.

Blust, Robert A. (1980). "Early Austronesian Social Organization the Evidence of Language”, Current Anthropology, 21(2), 205-266.

Blust, Robert A. (2008). Is there a Bima-Sumba Subgroup? Oceanic Linguistics Journal Nomor 47: 46-114. Honolulu: University of Hawaii.

Blust, Robert A. (2013). The Austronesian Languages. Revision Edition. Canberra: Pacific Linguistics.

Blust, Robert A. and S. Trussel. (2015). Austronesian Comparative Dictionary. Available online at ww.trussel2.com/ACD

Burhanuddin. (2017). "Hubungan Kekerabatan Bahasa Subrumpun Halmahera Selatan-Papua Barat di Halmahera Selatan". Disertasi Doktor. Surakarta: Universitas Sebelas Maret.

Holton, Gary dan Robinson, Laura C. (2014). The Internal History of Alor-Pantar Language Family. Dalam Marian Klamer ed. The Alor-Pantar Languages: History and Typology. Berlin: Language Science Press.

Kamholz, David Christopher. (2014). Austronesians in Papua: Diversification and Change in South Halmahera-West New Guinea. Disertasi for Doctor of Philosophy. Berkeley: University of California.

Lewis, M. Paul dkk, ed. 2015. Ethnologue: Languages of the world. $17^{\text {th }}$ edition. Dallas, Texas: Summer Institute of Linguistics, Inc. 